Mens

revue d'histoire intellectuelle de l'Amérique française

\title{
L’histoire du féminisme au Canada et au Québec : bibliographie sélective
}

\section{Sophie Doucet et Karine Hébert}

Volume 2, numéro 1, automne 2001

URI : https://id.erudit.org/iderudit/1024462ar

DOI : https://doi.org/10.7202/1024462ar

Aller au sommaire du numéro

Éditeur(s)

Centre de recherche en civilisation canadienne-française

ISSN

1492-8647 (imprimé)

1927-9299 (numérique)

Découvrir la revue

Citer ce document

Doucet, S. \& Hébert, K. (2001). L'histoire du féminisme au Canada et au

Québec : bibliographie sélective. Mens, 2(1), 125-144.

https://doi.org/10.7202/1024462ar 


\section{L'HISTOIRE DU FÉMINISME AU CANADA ET AU QUÉBEC : BIBLIOGRAPHIE SÉLECTIVE ${ }^{1}$}

SOPHIE DOUCET

Département d'histoire Université de Montréal

KARINE HÉBERT

Département d'histoire Université du Québec à Montréal

\section{PRÉSENTATION}

L'histoire du féminisme constitue un pont entre l'histoire des femmes et l'histoire intellectuelle car elle s'intéresse, entre autres, aux idées développées pour expliquer, justifier et parfois contester la place des femmes dans la société et dans l'histoire. Elle est une branche de l'histoire des femmes depuis les débuts de cette discipline à la fin des années soixante ${ }^{2}$. Même si ce genre historiographique est intimement lié à l'émergence de la deuxième vague du féminisme, il a également été rendu possible par les bouleversements qui agitaient la discipline historique à cette époque.

Au Canada, les pionnières du champ, soucieuses d'obtenir l'égalité entre les hommes et les femmes, ont favorisé des objets d'études, tel le droit de vote et la participation politique, qui mettaient en lumière l'engagement public des femmes, tout en s'attardant à l'oppression qu'elles avaient pu vivre (Clio, 1982). Mais dans leur quête d'égalité, elles ont souvent posé un jugement sévère sur leurs prédécesseures, allant jusqu'à constater l'échec de leurs luttes, inscrites au nom d'une différence plutôt que d'une égalité entre les sexes (Bacchi, 1982; Cleverdon, 1950 et 1974³ Pinard, 1979 et 1983). Assez 
rapidement, vers 1975, et de façon plus généralisée dans les années 1980, le mouvement féministe contemporain a évolué vers une valorisation de la différence des femmes (Prentice et al., 1988). Percevant les limites des études qui cherchaient à démontrer l'oppression des femmes, des chercheuses ont voulu élargir les perspectives en délimitant une «culture féminine» à l'intérieur de laquelle les femmes disposaient d'un certain contrôle et d'une certaine liberté. La sphère privée est devenue un objet d'étude privilégié et l'examen des luttes de femmes s'est diversifié. En même temps qu'elles étudiaient la vie privée et quotidienne des femmes, les historiennes se sont interrogées sur la place de celles-ci dans des mouvements qui n'étaient pas exclusivement féminins comme l'éducation, le mouvement ouvrier, le pacifisme, etc. (Bennett, 1986; Gorham et Williamson, 1989; Kealy et Sangster, 1989; MonetChartrand, 1993; Trofimenkoff, 1989).

Après avoir étudié les femmes dans le monde des hommes et les femmes dans le monde des femmes, et après avoir constaté les limites des deux approches, les historiennes ont remis en question l'existence de deux mondes hermétiquement séparés. Le concept de maternalisme a alors été proposé pour identifier une tendance féminine du début du siècle qui tentait d'élargir le rôle maternel des femmes dans la société, faisant ainsi le pont entre les deux mondes (Hébert, 1999). Il en a résulté une vague importante d'études sur le développement de l'État providence (Christie, 2000; Evans, 1997; Mitchinson, 1987). Ce questionnement sur les liens entre le privé et le public s'est accompagné d'un intérêt pour les interactions entre les hommes et les femmes et de l'émergence d'un nouveau courant : l'histoire du genre (Iacovetta et Kealey, 1996; Parr, 1995; Sangster, 1995). Ce courant est concomitant avec l'émergence du postmodernisme et met l'accent sur la construction sociale et discursive de la féminité et de la masculinité. Il s'accompagne aussi d'une reconnaissance de la multiplicité des identités. C'est donc dire que les femmes ne se définissent plus uniquement par leur féminité, mais aussi par la classe, l'ethnicité, la religion ou l'orientation sexuelle (Agnew, 1993; Cohen, 1990; Lachapelle, 1982; Lamoureux, 1993; Roy, 1985; Pal, 1993). 
Les lignes qui précèdent brossent un portrait général de l'histoire des femmes et du féminisme au Canada et au Québec. Mais certaines particularités distinguent la pratique des historiennes du Québec, notamment en ce qui concerne les sujets qu'elles ont privilégiés. Les chercheuses d'ici peuvent, par exemple, être reconnues comme des pionnières dans un champ d'étude qui se développe depuis 1975 et qui examine les liens entre la question nationale et le féminisme. (De Sève, 1998; Lamoureux, 1987; Trofimenkoff, 1975 et 1986). Les nombreux travaux réalisés sur l'histoire des religieuses sont aussi particuliers à l'historiographie des femmes québécoises. Par ailleurs, les questionnements postmodernes et d'éclatement identitaire si populaires au Canada anglais et aux États-Unis n'a pas encore suscité le même engouement parmi les historiennes québécoises ${ }^{4}$. Les choix historiographiques des historiennes des femmes au Québec s'inscrivent donc à la fois dans le développement du genre historique qu'elles pratiquent et dans le celui de l'historiographie québécoise en général.

Les travaux qui ont été sélectionnés pour cette bibliographie se penchent sur le féminisme au Québec et dans l'ensemble du Canada. Ceux qui portaient sur des régions spécifiques du Canada, autres que le Québec, ont été délibérément exclus. Cette bibliographie comprend six sections: A)Instruments de recherche et ouvrages de référence; B)Historiographie de l'histoire des femmes et du féminisme; C)Féminisme et antiféminisme; D)Histoire des mouvements et des luttes féministes; E)Figures du féminisme et F)Critiques féministes des disciplines. Dans la section «Figures du féminisme», nous n'avons retenu que les ouvrages portant sur les féministes les plus connues, en accordant une attention particulière aux féministes québécoises. Dans la dernière catégorie, nous avons choisi des travaux qui montrent comment le féminisme a influencé et s'est intégré dans les autres sciences sociales. Ce panorama couvre les années 1950 à 2000. Nous avons exclu les mémoires de mâ̂trise puisqu'ils sont difficilement accessibles. 
Avant de plonger dans ces travaux, le lecteur consultera avec profit les deux grandes synthèses sur l'histoire des femmes au Canada et au Québec : Collectif Clio, L'histoire des femmes au Québec depuis quatre siècles, Montréal, Le Jour, 1992 (1982, première édition); et Prentice, Alison et al. Canadian Women. A History, Toronto, Harcourt Brace Jovanovich, 1996 (1988, première édition). Il existe aussi quelques grands recueils d'articles, dont : Prentice, Alison et Susan Mann Trofimenkoff, dirs. The Neglected Majority: Essays in Canadian Women's History, Toronto, McClelland and Stewart, 1977 et 1985, 2 volumes; et Strong-Boag, Veronica et Anita Clair Fellman, Rethinking Canada: The Promise of Women's History, Toronto, Copp Clark Pitman, 1991.

\section{A) Instruments de recherche et ouvrages de références}

BRADBURY, Bettina. «Femmes et familles» dans Jacques ROUILLARD, dir. Guide d'histoire du Québec du régime français à nos jours. Bibliographie commentée, Montréal, Éditions du Méridien, 1993, p. 213-228.

COHEN, Yolande. Les thèses québécoises sur les femmes. Québec, Institut québécois de recherche sur la culture, 1983. (Coll. «Instruments de travail, $\mathrm{n}^{\circ} 7$ )).

COMITÉ CANADIEN D'HISTOIRE DES FEMMES. Bulletins, 1995-2000.

CORBEIL, Christine et Francine DESCARIES. Femmes, féminisme et maternité. Une bibliographie sélective. Montréal, Université du Québec à Montréal, Centre de recherche féministe Département de travail social, 1989.

DARSIGNY, Maryse. Ces femmes qui ont bâti Montréal. La petite et la grande histoire des femmes qui ont marqué la vie de Montréal depuis 350 ans. Montréal, Éditions du Remueménage, 1994. 
DYER, Klay, Sue MARTIN et Lucy SUSSEX. The Canadian Women's History Bibliography. Ottawa, Canadian Institute for Historical Microreproductions, 1997.

LEMIEUX, Denise et Lucie MERCIER. La recherche sur les femmes au Québec: bilan et bibliographie. Montréal, Institut québécois de recherche sur la culture, 1982. (Coll. «Instruments de travail, $\left.\mathrm{n}^{0} 5 »\right)$.

MARCHAND, Suzanne. Femmes et histoire. Bilan de la production universitaire québécoise, 1970-1993. Québec, Université Laval, Les cahiers de recherche du GREMF, 1994.

MONET-CHARTRAND, Simonne, Pionnières québécoises et regroupements de femmes d'hier à aujourd'hui. Montréal, Éditions du Remue-ménage, 1990.

MONET-CHARTRAND, Simonne. Pionnières québécoises et regroupements de femmes, 1970-1990. Montréal, Éditions du Remue-ménage, 1994.

O'LEARY, Véronique et Louise TOUPIN. Québécoises deboutte! Tome 1, Une anthologie de textes du Front de libération des femmes (1969-1971) et du Centre des femmes (1972-1975). Montréal, Éditions du Remue-ménage, 1982.

O'LEARY, Véronique et Louise TOUPIN. Québécoises deboutte! Tome 2, Collection complète suivie de deux tables rondes avec des femmes du Front de libération des femmes (1969-1971) et du Centre des femmes (1972-1975). Montréal, Éditions du Remue-ménage, 1983.

PEDERSON, Diana. Changing Women, Changing History. Ottawa, Carleton University Press, 1996.

PIERSON, Ruth Roach, et al. Canadian Women's Issues. 2 volumes. Toronto, James Lorimer \& Company Publishers, 1993. 
RANDALL, Melanie. «Feminist Theory, Political Philosophy and the Politics of Reproduction: An Annotated Bibliography». Resources for Feminist Research, vol. 18, n³ (1989), p. 111-122.

Women Unite!: An Anthology of the Canadian Women's Movement. Toronto, Canadian Women's Educational Press, 1972.

\section{B) Historiographie de l'histoire des femmes et du féminisme}

BAILLARGEON, Denyse. «Des voies/x parallèles. L'histoire des femmes au Québec et au Canada anglais (1970-1995)». Sextant Revue du groupe interdisciplinaire d'études pour les femmes, $\mathrm{n}^{\circ}$ 4 (1995), p. 133-168.

BAILLARGEON, Denyse. «Histoire et historiennes». Bulletin de l'Association des études canadiennes, vol. 18, n" 4 (hiver 19961997), p. 16-17, 20.

BOUTILIER, Beverly et Alison PRENTICE, dirs. Historical Memory: English-Canadian Women and the Work of History. Vancouver, University of British Columbia Press, 1997.

BRANDT, Gail Cuthbert. «Postmodern Patchwork: Some Recent Trends in the Writing of Women's History in Canada». Canadian Historical Review, vol. 72, nº 4 (décembre 1991), p. 441-470.

DUMONT, Micheline. «The Influence of Feminist Perspectives on Historical Research Methodology» dans Winnifred TOMM, dir. The Effects of Feminist Approches on Research Methodologies, Waterloo, Wilfrid Laurier University Press, 1989, p. 111-129.

DUMONT, Micheline. «L'histoire nationale peut-elle intégrer la réflexion féministe sur l'histoire?» dans Robert COMEAU et Bernard DIONNE, dirs. À propos de l'histoire nationale, Québec, Septentrion, 1998, p. 19-36.

DUMONT, Micheline, «Un champ bien clos. L'histoire des femmes au Québec». Atlantis, vol. 25, nº 1 (automne 2000), p. 102-118. 
FAHMY-EID, Nadia. «L'histoire des femmes : construction et déconstruction d'une mémoire sociale». Sociologie et sociétés, vol. 29, nº (automne 1997), p. 21-30.

IACOVETTA, Franca et Linda KEALEY. «Women's History, Gender History and Debating Dichotomies». Left History, vol. 3, n 2 (automne 1995) et vol. 4, nº 1 (printemps 1996), p. 221-237.

KEALEY, Linda. «Crossing Borders: The Influence of American Women's History on the Writing of Canadian Women's History». Canadian Review of American Studies, Special Issue, Part. II (1992), p. 279-300.

LÉVESQUE, Andrée. "Réflexions sur l'histoire des femmes dans l'histoire du Québec». Revue d'histoire de l'Amérique française, vol. 51, no 2 (automne 1997), p. 271-284.

OUELLET, Fernand. «La question sociale au Québec, 1880-1930 : la condition féminine et le mouvement des femmes dans l'historiographie». Histoire sociale / Social History, vol. 21, nº 42 (novembre 1988), p. 319-345.

PARR, Joy. «Gender History and Historical Practice». Canadian Historical Review, vol. 76, nº 3 (septembre 1995), p. 354-376.

PIERSON, Ruth Roach. «Experience, Difference, Dominance and Voice in the Writing of Canadian Women's History» dans Karen OFFEN, Ruth Roach PIERSON et Jane RENDALL, dirs. Writing Women's History: International Perspectives, Bloomington, Indiana University Press, 1991, p. 79-106.

SANGSTER, Joan. «Beyond Dichotomies: Pre-Assessing Gender History and Women's History in Canada». Left History, vol. 3, no 1 (1995), p. 109-121.

TOUPIN, Louise. «Une histoire du féminisme est-elle possible?». Recherches féministes, vol. 6, nº 1 (1993), p. 25-51. 
TROFIMENKOFF, Susan Mann. «Nationalism, Feminism and Canadian Intellectual History». Canadian Literature, n" 83 (hiver 1979), p. 7-20.

VAN KIRK, Silvia. «What Has the Feminist Perspective Done for Canadian History?» dans Ursula Martius FRANKLIN, et al., dir. Knowledge Reconsidered: A Feminist Overview, Ottawa, Canadian Research Institute for the Advancement of Women, 1984, p. 46-58.

\section{C) Féminisme et antiféminisme}

\section{$\underline{\text { Articles }}$}

AGNEW, Vijay. "Canadian Feminism and Women of Colour». Women's Studies International Forum, vol. 16, n 3, (1993), p. 217-227.

BASHEVKIN, Sylvia. "Losing Common Ground: Feminists, Conservatives and Public Policy in Canada during the Mulroney Years». Canadian Journal of Political Science, vol. 29, n² 2 (juin 1996), p. 211-242.

CLICHE, Marie-Aimée. «Droits égaux ou influence accrue? Nature et rôle de la femme d'après les féministes chrétiennes et les anti-féministes au Québec, 1896-1930». Recherches féministes, vol. 2, n"2 (1989), p. 101-119.

COHEN, Yolande. «Du féminin au féminisme : l'exemple québécois» dans Georges DUBY et Michelle PERROT, dirs. Histoire des femmes. Tome 5 : Le vingtième siècle, Paris, Plon, 1992, p. 521-538.

CURRIE, Dawn H. «Representation and Resistance: Feminist Struggles Against Pornography» dans Dawn H CURRIE and Valerie RAOUL, dirs. The Anatomy of Gender: Women's Struggle for the Body, Ottawa, Carleton University Press, 1992, p. 191-208. 
DAIGLE, Johanne. «Le siècle dans la tourmente du féminisme». Globe, vol. 3, no 2 (2000), p. 65-86.

DE SĖVE, Micheline. «Féminisme et nationalisme au Québec, une alliance inattendue». International Journal of Canadian Studies, vol. 17 (printemps 1998), p. 157-176.

HAMILTON, Roberta. «Feminism and Motherhood, 1970-1990: Reinventing The Wheel?». Resources for Feminist Research, vol. 19 (septembre-décembre 1990), p. 23-32.

HAMILTON, Roberta. «Feminist Theories». Left History, vol. 1, $\mathrm{n}^{0}$ 1 (printemps 1993), p. 9-33.

JANOVICEK, Nancy. «Feminism, Debate and Social Change: Recent Anthologies on Feminist Theory and Praxis». Revue d'études canadiennes / Journal of Canadian Studies, vol. 33, $\mathrm{n}^{\mathrm{0}} 1$ (printemps 1998), p. 163-172.

JEAN, Michèle. «Féminisme et religion au Québec, 1900-1978» dans Élizabeth J. LACELLE, dir. La femme et la religion au Canada français, Montréal, Éditions Bellarmin, 1979, p. 33-42.

LAMOUREUX, Diane. «Nationalism and Feminism in Quebec: An Impossible Attraction» dans Heather Jon MARONEY and Meg LUXTON, dirs. Feminism and Political Economy: Women's Work, Women's Struggles, Toronto, Methuen, 1987, p. 51-68.

MAILLÉ, Chantale. «Féminisme et mouvement des femmes au Québec. Un bilan complexe». Globe, vol. 3, n 2 (2000), p. 87-106.

STRONG-BOAG, Veronica. «Independent Women, Problematic Men: First - and Second - Wave Anti-Feminism in Canada from Goldwin Smith to Betty Steele». Histoire sociale / Social History, vol. 29, nº 57 (mai 1996), p. 1-22.

TROFIMENKOFF, Susan. «Henri Bourassa and the Woman Ques- 
tion». Revue d'études canadiennes / Journal of Canadian Studies, vol. 10, n'4(1975), p. 3-11.

TROFIMENKOFF, Susan. «Feminism, Nationalism and the Clerical Defensive» dans Veronica STRONG-BOAG et Anita Clair FELLMAN, dirs. Rethinking Canada: The Promise of Women's History, Toronto, Copp Clark, 1986, p. 123-136

\section{Volumes}

BOYD, Susan B. dir. Challenging the Public/Private Divide: Feminism, Law, and the Public Policy. Toronto, University of Toronto Press, 1997.

COLLARD, Nathalie et Pascale NAVARRO. Interdit aux femmes. Le féminisme et la censure de la pornographie. Montréal, Boréal, 1996.

DUMAIS, Monique. La mère dans la société québécoise. Étude éthique d'un modèle à partir de deux journaux féministes: La Bonne parole et Les Têtes de pioches. Ottawa, Les documents de l'ICREF, n" 8, 1983.

GAGNON, Mona-Josée. Les femmes vues par le Québec des hommes : 30 ans d'histoire des idéologies. Montréal, Éditions du Jour, 1974.

GAGNON, Nicole. L'antiféminisme. Montréal, Stanké, 1998.

GUETTEL, Charnie. Marxism and Feminism. Toronto, Women's Press, 1974.

HAMILTON, Roberta et Michèle BARRETT, dirs. The Politics of Diversity : Feminism, Marxism and Nationalism. Montréal, Book Centre Inc., 1986.

LAMOUREUX, Diane. Fragments et collages. Essai sur le féminisme québécois des années 1970. Montréal, Éditions du Remueménage, 1986. 
LAMOUREUX, Diane, Entre le féminin et le féminisme. Québec, Laboratoire d'études politiques et administratives, Département de science politique, Faculté des sciences sociales, Université Laval, 1991.

MILES, Angela et Geraldine FINN, dirs. Feminism: From Pressure to Politics. Montréal, Black Rose Books, 1988.

PAL, Leslie A. Interests of State: The Politics of Language, Multiculturalism, and Feminism in Canada. Montréal et Kingston, McGill-Queen's University Press, 1993.

RISTOCK, Janice et Jeri Dawn WINE, dirs. Women and Social Change: Feminist Activism in Canada. Toronto, James Lorimer and Company, 1991.

TOUPIN, Louise. Mères ou citoyennes? Une critique du discours historique nord-américain (1960-1990) sur le mouvement féministe (1850-1960). Thèse de Ph.D. (sciences politiques), Université du Québec à Montréal, 1994.

\section{E) Histoire des mouvements et des luttes féministes}

\section{$\underline{\text { Articles }}$}

BENNETT, Paul. «The Canadian Women's Movement, 18801920s: A Struggle for Political Rights or Social Reform?» dans Paul W. BENNETT et Cornelius J. JAENEN, dirs. Emerging Identities: Selected Problems and Interpretations in Canadian History, Scarborough, Prentice-Hall Canada, 1986, p. 376-405.

DANYLEWYCZ, Marta. «Une nouvelle complicité : féministes et religieuses à Montréal, 1890-1925» dans Marie LAVIGNE et Yolande PINARD, dirs. Travailleuses et féministes. Les femmes dans la société québécoise, Montréal, Boréal Express, 1983, p. 245-270.

DESJARDINS, Marc. «Les lièvres et les tortues? Les mouvements féministes et le droit à l'égalité aux États-Unis et au Ca- 
nada». Études canadiennes / Canadian Studies, n” 33 (1992), p. 235-248.

DES RIVIÈRES, Marie-José. «La vie en rose (1980-1987) : un magazine féministe haut en couleur». Recherches féministes, vol. $8, n^{\prime \prime} 2$ (1995), p. 127-136.

DUMONT, Micheline. «The Origins of the Women's Movement in Quebec» dans Constance BACKHOUSE et David H. FLAHERTY, dirs. Challenging Time: The Women's Movement in Canada and the Unites States, Montréal et Kingston, McGillQueen's University press, 1992, p. 72-92.

DUMONT, Micheline. «La parole des femmes. Les revues féminines, 1938-1968» dans Fernand DUMONT, Jean HAMELIN et J.-P. MONTMINY, dirs. Idéologies au Canada français, 19401976. Tome 2, Québec, Presses de l'Université Laval, 1981, p. 546.

GORHAM, Deborah. «The Canadian Suffragists» dans Gwen MATHESON, dir., Women in The Canadian Mosaic, Toronto, Peter Martin Associates, 1976, p. 23-56.

GORHAM, Deborah et Florence Kellner ANDREWS. «The La Leche League: A Feminist Perspective» dans Katherine ARNUP, Andrée LÉVESQUE and Ruth Roach PIERSON, dirs. Delivering Motherhood: Maternal Ideologies and Practices in the $19^{\text {th }}$ and $20^{\text {th }}$ Centuries, London et NewYork, Routledge, 1990 , p. 238-269.

HÉBERT, Karine. «Une organisation maternaliste au Québec : la Fédération nationale Saint-Jean-Baptiste et la bataille pour le vote des femmes». Revue d'histoire de l'Amérique française, vol. 52, no 3 (hiver 1999), p. 315-344.

HOBBS, Margaret. «Equality and Difference: Feminism and the Defence of Women Workers During the Great Depression». 
Labour / Le travail, no 32 (automne 1993), p. 201-23. Aussi dans Wendy MITCHINSON et al., dir. Canadian Women: A Reader, Toronto, Harcourt Brace Canada, 1996, p. 212-233.

JAMIESON, Kathleen. «Multiple Jeopardy: The Evolution of a Native Women's Movement». Atlantis, vol. 4, nº 2 (1979), p. 157-178.

JEAN, Michèle. «Histoire des luttes féministes au Québec». Possibles, vol. 4, $\mathrm{n}^{\circ} 1$ (automne 1979), p. 17-32.

LACHAPELLE, Caroline. "Beyond Barriers: Native Women and the Women's Movement» dans Maureen FITZGERALD, Connie GUBERMAN and Margie WOLFE, dirs. Still Ain't Satisfied!: Canadian Feminism Today, Toronto, The Women's Press, 1982, p. 257-264.

LAVIGNE, Marie, Yolande PINARD et Jennifer STODDART. «La Fédération nationale Saint-Jean-Baptiste et les revendications féministes au début du $20^{\circ}$ siècle» dans Marie LAVIGNE et Yolande PINARD, dirs. Travailleuses et féministes. Les femmes dans la société québécoise, Montréal, Boréal Express, 1983. p. 199216.

LEMIEUX, Denise. «Mouvements sociaux et culture. Le mouvement féministe au Québec». Revue d'études canadiennes / Journal of Canadian Studies, vol. 30, no 1 (printemps 1995), p. 75-89.

MITCHINSON, Wendy. «Early Women's Organisations and Social Reform: Prelude to the Welfare State» dans Allan MOSCOVITCH et Jim ALBERT dirs. The 'Benevolent' State: The Growth of Welfare in Canada, Toronto, Goromond Press, 1987, p. 77-92.

PINARD, Yolande. «Les débuts du mouvement des femmes à Montréal, 1893-1902» dans Marie LAVIGNE et Yolande PINARD, dirs. Travailleuses et féministes. Les femmes dans la société québécoise, Montréal, Boréal Express, 1983, p. 177-198. 
PORTER, Marilyn et June CORMAN, dirs. «Feminism and the New Right in Canada». Special Issue, Atlantis, vol. 21, n" 2 (printemps 1997).

STRONG-BOAG, Veronica. «Claiming a Place in the Nation: Citizenship Education and the Challenge of Feminists, Natives and Workers in Post-Confederation Canada». Canadian and International Education, vol. 25, n 2 (1997), p. 128-145.

STRONG-BOAG, Veronica. «Peace-making Women: Canada, 19191939» dans Ruth Roach PIERSON, dir. Women and Peace: Theoretical, Historical and Practical Perspectives, London, Croom Helm, 1987, p. 170-191.

VALVERDE, Mariana. «When the Mother of the Race is Free': Race, Reproduction and Sexuality in First-Wave Feminism» dans Franca IACOVETTA et Mariana VALVERDE, dirs. Gender Conflicts: New Essays in Women's History, Toronto, University of Toronto Press, 1992, p. 3-26.

\section{Volumes}

ADAMSON, Nancy, Linda BRISKIN et Margaret McPHAIL. Feminist Organizing for Change: The Contemporary Women's Movement in Canada. Toronto, Oxford University Press, 1988.

BACCHI, Carol. Liberation Deffered? The Ideas of the English Canadian Suffragists, 1877-1918. Toronto, University of Toronto Press, 1982.

BACKHOUSE, Constance et David H. FLAHERTY, dirs. Challenging Times: The Women's Movement in Canada and the United States. Montréal et Kingston, McGill-Queen's University Press, 1992.

BAINES, Carol. Women's Reform Organisations in Canada, 1870 1930. Toronto, Faculty of Social Work, University of Toronto, 1988. 
BLACK, Naomi et Gail Cuthbert BRANDT. Feminist Politics on the Farm: Rural Catholic Women in Southern Quebec and Southwestern France. Montréal et Kingston, McGill-Queen's University Press, 1999.

BURT, Sandra, Lorraine CODE and Lindsay DORNEY, dirs. Changing Patterns: Women in Canada. Toronto, McClelland and Stewart, 1993.

CARTY, Linda, dir. And Still We Rise: Feminist Political Mobilizing in Contemporary Canada. Toronto, Women's Press, 1993.

CHRISTIE, Nancy. Engendering the State: Family, Work, and Welfare in Canada. Toronto, University of Toronto Press, 2000.

CLEVERDON, Catherine Lyle. The Woman Suffrage Movement in Canada. Toronto, University of Toronto Press, 1974 [1950].

COHEN, Yolande, dir. Femmes et politique. Montréal, Le Jour, 1981.

COHEN, Yolande. Femmes et contre-pouvoir. Montréal, Boréal Express, 1987.

COHEN, Yolande. Femmes de parole. L'histoire des cercles de fermières du Québec, 1915-1990. Montréal, Le Jour, 1990.

EVANS, Patricia M. et Gerda R. WEKERLE, dirs. Women and the Canadian Welfare State: Challenges and Change. Toronto, University of Toronto Press, 1997.

FEMMES EN TÊTE. De travail et d'espoir. Des groupes de femmes racontent le féminisme. Montréal, Éditions du Remue-ménage, 1990.

FUDGE, Judy et Patricia McDERMOTT, dirs. Just Wages: A Feminist Assessment of Pay Equity. Toronto, University of Toronto Press, 1991.

GORHAM, Deborah et Janice WILLIAMSON, dir. Up and Doing: Canadian Women and Peace. Toronto, The Women's Press, 1989. 
GRIFFITHS, N.E.S. The Splendid Vision: Centennial History of the National Council of Women of Canada, 1893-1993. Ottawa, Carleton University Press, 1993.

HUGUES, Nym, Yvonne JOHNSON et Yvette PERREAULT. Stepping Out of the Line: A Workbook on Lesbianism and Feminism. Vancouver, Press Gang, 1984.

KEALEY, Linda. A Not Unreasonable Claim: Women and Reform in Canada, 1880-1920. Toronto, The Women's Press, 1979.

KEALEY, Linda. Enlisting Women for the Cause: Women, Labour, and the Left in Canada, 1890-1920. Toronto, University of Toronto Press, 1998.

KEALEY, Linda et Joan SANGSTER. Beyond the Vote: Canadian Women and Politics. Toronto, University of Toronto Press, 1989.

LAMOUREUX, Diane. Citoyennes? Femmes, droit de vote et démocratie. Montréal, Éditions du Remue-ménage, 1989.

LAMOUREUX, Jocelyne, Michèle GÉLINAS et Katy TARI. Femmes en mouvement: Trajectoires de l'Association féminine d'éducation et d'action sociale, AFÉAS, 1966-1991. Québec, Boréal, 1993.

MAILLÉ, Chantal. Les Québécoises et la conquête du pouvoir politique. Montréal, Éditions Saint-Martin, 1990.

MONET-CHARTRAND, Simonne. Les Québécoises et le mouvement pacifiste, 1939-1967. Montréal, Les Éditions écosociété, 1993.

NEWTON, Janice. The Feminist Challenge to the Canadian Left, 1900-1918. Montréal et Kingston, McGill-Queen's University Press, 1995.

ROY, C. Les lesbiennes et le féminisme. Montréal, Éditions SaintMartin, 1985. 
STRONG-BOAG, Veronica. The Parliament of Women: The National Council of Women of Canada, 1893-1929. Ottawa, Musée national de l'homme, 1976.

THOM, Heather. To Be a Woman: Feminism and the Women's Movement. Toronto, Umbrella Press, 1997.

VINEBERG, Ethel. The History of the National Council of Jewish Women of Canada. Montréal, National Council of Jewish Women of Canada, 1967.

WALKER, Gillian A. Family Violence and the Women's Movement: The Conceptual Politics of Struggle. Toronto, University of Toronto Press, 1990.

\section{F) Figures du féminisme}

CONRAD, Margaret. «"Not a Feminist, But...”: The Political Career of Ellen Louks Fairclough, Canada's First Female Federal Cabinet Minister». Revue d'études canadiennes / Journal of Canadian Studies, vol. 31, nº 2 (été 1996), p. 5-28.

DARSIGNY, Maryse. «La "femme moderne" selon Thérèse Casgrain : une analyse de son discours féministe des années trente» dans Anita CARON, dir. Thérèse Casgrain. Une femme tenace et engagée, Sainte-Foy, Presses de l'Université du Québec, 1993.

FRENCH, Doris. Ishbel and the Empire: a Biography of Lady Aberdeen. Toronto, Dundurn Press, 1988.

HALLETT, Mary and Marilyn DAVIS. Firing the Heather: The Life and Times of Nellie McClung. Saskatoon, Fifth House, 1993.

LACELLE, Nicole. Madeleine Parent, Léa Roback. Entretiens avec Nicole Lacelle. Montréal, Éditions du Remue-ménage, 1988.

LAMOUREUX, Diane. «Idola Saint-Jean et le radicalisme fémi- 
niste de l'entre-deux-guerres». Recherches féministes, vol. 4, n"2 (1991), p. 45-60.

PELLETIER-BAILLARGEON, Hélène. Marie Gérin-Lajoie. De mère en fille, la cause des femmes. Montréal, Boréal, 1985.

PELlETIER-BAILlARGEON, Hélène, et al. Simonne MonetChartrand: Un héritage et des projets. Montréal, Éditions Fides / Éditions du Remue-ménage, 1993.

ROOKE, Patricia T. et R. L. SCHNELL. No Bleeding Heart: Charlotte Whitton, A Feminist on the Right. Vancouver, University of British Columbia Press, 1987.

STRONG-BOAG, Veronica. «Even a Crusader': Nellie McClung, First Wave Feminist» dans Veronica STRONG-BOAG et Anita Clair FELLMAN, dirs. Rethinking Canada: The Promise of Women's History, Toronto, Copp Clark, 1986, p. 178-190; $2^{`}$ édition, 1991, p. 308-321.

TROFIMENKOFF, Susan. "Thérèse Casgrain and the CCF in Quebec» dans Linda KEALEY et Joan SANGSTER, dirs. Beyond the Vote: Canadian Women and the Politics, Toronto, University of Toronto Press, 1989, p. 139-168.

\section{G) Critiques féministes des disciplines}

ANDREW, Caroline, dir. Getting the Word Out: Communicating Feminist Research. Ottawa, University of Ottawa Press, 1989.

BOURNE, Paula, et al. dir. Feminism and Education: A Canadian Perspective. Volume 2. Toronto, Centre for Women's Studies in Education, Ontario Institute for Studies in Education, 1994.

BURT, Sandra et Lorraine CODE, dirs. Changing Methods: Feminists Transforming Practice. Peterborough, Broadview Press, 1995. 
CARON, Anita, dir. Femmes et pouvoir dans l'Église. Montréal, VLB Éditeur, 1991.

DAGENAIS, Hugette, dir. Science, conscience et action. 25 ans de recherche féministe au Québec. Montréal, Éditions du Remueménage, 1996. (Coll. «Itinéraires féministes»).

DESCARRIES-BÉLANGER, Francine et Micheline de SÈVE. Bilan et perspectives de recherches féministes. Ottawa, ICREF, 1985.

EICHLER, Margrit and Jeanne LAPOINTE. On the Treatment of the Sexes in Research. Ottawa, Social Science and Humanities Research Council of Canada, 1985.

GREENHILL, Pauline et Diane TYE. «Folklore, féminisme et études féministes au début des années 1990» dans Anne-Marie DESDOUITS et Laurier TURGEON, dirs. Ethnologies francophones de l'Amérique et d'ailleurs, Québec, Presses de l'Université Laval, 1997, p. 119-136.

PIERSON, Ruth et Alison PRENTICE. «Feminism and the Writing of and Teaching of History». Atlantis, vol. 7, $\mathrm{n}^{\mathrm{0}} 2$ (printemps 1982), p. 37-46. Aussi dans Terry CROWLEY, dir. Clio's Craft : A Primer of Historical Methods, Toronto, Copp Clark Pitman, 1988, p. 211224.

ROBINSON, Gertrude. «Monopolies of Knowledge in Canadian Communication Studies: The Case of Feminist Approaches». Canadian Journal of Communications, vol. 23, n" 1 (hiver 1998), p. 65-72.

SHARP, Carolyn. «The Emergence of Francophone Feminist Theology». Studies in Religion / Sciences religieuses, vol. 25, $\mathrm{n}^{\circ} 4$ (1996), p. 397-407.

TANCRED, Peta. «Into the Third Decade of Canadian Women's Studies: A Glass Half Empty or Half Full?». Women's Studies 
Quarterly, vol. 22, n“ 3 et 4 (automne-hiver 1994-1995), p. 12-25. TANCRED-SHERIFF, Peta, dir. Feminist Research: Prospect and Retrospect, Montréal et Kingston, McGill-Queen's University Press, Canadian Research Institute for the Advancement of Women, 1988.

\section{NOTES}

'Nous tenons à remercier Denyse Baillargeon pour ses commentaires judicieux.

${ }^{2}$ Les débuts de l'histoire des femmes, tout comme ceux de la deuxième vague du féminisme, proviennent des États-Unis. On peut penser aux travaux précurseurs de Mary Beard (Woman as a Force in History: A Study of Traditions and Realities, New York, Collier Books, 1946) et d'Eleonor Flexner (Century of Struggle: The Woman's Rights Movement in the United States, 1877-1918, Cambridge, Harvard University Press, 1959).

${ }^{3}$ Cleverdon en publicant son ouvrage en 1950 fait elle aussi figure, sinon de visionnaire, du moins de pionnière de l'histoire des femmes au Canada.

${ }^{4}$ Denyse Baillargeon propose des explications intéressantes à ce sujet dans «Des voies parallèles. L'histoire des femmes au Québec et au Canada anglais (1970-1995)», Sextant - Revue du groupe interdisciplinaire d'études pour les femmes, no 4, 1995, p. 133168. 